\title{
Elementos de uma semiótica da narratividade musical
}

\section{Christian Hauer}

Resumo : Para responder a questão "a que nível semiótico comunica-se a música?", distinguimos três fluxos semióticos da narratividade musical. 0 primeiro fluxo de narratividade é chamado de "substância": ele corresponde à narratividade primária, presente em todas as músicas, dentro do próprio som. O segundo fluxo de narratividade musical é chamado de "moldura": ele corresponde à maneira como é organizado o tempo - problematizado dentro de uma obra, um estilo, uma época. O terceiro fluxo de narratividade é chamado de "enredo": ele corresponde à trama de uma obra. Após ter precisado em que isso consiste, graças ao conceito de "tensão narrativa", nós estudamos sua realização pelo ouvinte, e mais precisamente a interação entre o leitor e o texto, insistindo em três fatores que tornam tal interação possível: a intencionalidade, a embodied simulation e as formas de vitalidade.

Résumé : Pour répondre à la question "à quel niveau sémiotique la musique communique-telle ?", nous distinguons trois flux sémiotiques de la narrativité musicale. Le premier flux de narrativité est appelé "substance" : il correspond à la narrativité primaire, présente en toute musique, dans le son même. Le deuxième flux de narrativité est appelé "cadre" : il correspond à la manière dont le temps est organisé - problématisé - dans une oeuvre, un style, une époque. Le troisième flux de narrativité est appelé "intrigue" : il correspond à la mise en intrigue d'une oeuvre. Après avoir précisé en quoi celle-ci consiste, grâce au concept de «tension narrative ", nous étudions son actualisation par l'auditeur, et plus précisément l'interaction entre le lecteur et le texte, en insistant sur trois facteurs qui rendent une telle interaction possible: l'intentionnalité, l'embodied simulation et les formes de vitalité.

1 Tradução de Rafael Alexandre da Silva, a partir do texto original em francês cujo pdf foi enviado pelo autor. à editora-chefe desta publicação. 


\section{Terminologia}

Precisaremos inicialmente de um elemento de terminologia: a distinção entre "narratividade" e "narratologia". "Narratividade" exprime o fato de ser narrativo; trata-se de uma propriedade, de uma qualidade, e não de um constituinte; é de qualquer modo o caráter narrativo do narrativo, não aquilo que é narrado, mas o que ocorre para que haja um narrado e uma narrativa que se apresenta de uma certa maneira; por consequência, o ponto semiótico, a pedra angular da significação é aqui constituído por aquilo que produz narratividade. "Narratologia" é um termo que pode "ser empregado para designar todas as abordagens pensadas do estudo do discurso organizado narrativamente, quer seja literário, historiográfico, conversacional, fílmico ou outro" (HERMAN apud PIER \& BERTHELOT, 2010, p. 9); a narratologia é mais geralmente uma disciplina científica, mais ou menos constituída, "dedicada ao estudo da lógica, dos princípios e das práticas da representação narrativa" (MEISTER, 2011). A narratologia estuda então a maneira pela qual a narratividade se desdobra através do tempo.

Nossa hipótese é que essa narratividade não é uma, em um único bloco, mas múltipla. De onde a proposição, para responder à questão "a que nível semiótico comunica-se a música?", de distinguir três fluxos semióticos da narratividade musical. "Fluxo" e não "nível", "plano", "camada" ou "estrutura": esses termos poderiam sugerir uma superposição, uma hierarquia, uma passagem progressiva do profundo do subjacente - à superfície, àquilo que aparece. Esse não é o caso: esses fluxos não se opõem nem mesmo se completam; eles são emaranhados, co-presentes em permanência, distintos, mas não separados; eles nutrem a música, lhes levam profundidade e intensidade. Podemos a partir disso formular os dois principais objetivos deste artigo. 


\section{Objetivos}

Primeiro objetivo: apresentar os fluxos da narratividade que atuam em conjunto sobre a experiência musical, e distinguiremos três. Uma explicitação importante: não pretendemos apresentar aqui um tipo de sistema fechado, até mesmo teórico, mas uma série de proposições que tem por finalidade compreender de maneira mais refinada como funciona a narratividade musical. Quais são esses três fluxos da narratividade? Primeiro, uma narratividade "substância", que retorna a uma "narratividade primeira [...] latente em toda música" (CHARLES, 2001 , p. 101), correspondente ao "murmurinho mesmo do existir" (ibid., p. 110). Em seguida, uma narratividade "moldura", que associamos àquilo que poderíamos chamar o modo de organização temporal própria de um tempo, um lugar, um estilo ou ainda um compositor; por consequência, uma narrativa como expressão de uma situação particular. Finalmente, uma narratividade "enredo", que corresponde à maneira pela qual o desenvolvimento da trama musical é atualizado pelo leitor.

Do segundo objetivo: ele corresponde de fato ao estudo daquele último fluxo de narratividade, para fazer deste o lugar próprio de um tratado narratológico da obra musical. E aqui, do ponto de vista da narratologia dita "pós-clássica", que desenvolveu entre outros uma abordagem cognitiva das histórias literárias (para uma referência sobre o desenvolvimento da ou das narratologias, ver Nünning, 2010). Nos apoiamos nos trabalhos de Raphaël Baroni sobre a "tensão narrativa", que aborda o enredo do ponto de vista do efeito produzido sobre o leitor (BARONI, 2011; 2010; 2007). Com efeito, é "impossível tratar da tensão narrativa sem levar em consideração a participação cognitiva e afetiva do leitor na realização do texto" (BARONI, 2010, p. 202). Em seguida, 
examinaremos alguns dos fatores que tornam possível e nutrem tal participação, ou interação.

\section{A narratividade substância}

Para tratar do primeiro fluxo da narratividade, chamado "substância", não abordaremos de maneira profunda a questão espinhosa - já tão debatida - da relação entre tempo e música, e ainda mais do tempo musical. Uma questão simples servirá de ponto de partida para a nossa reflexão: sob o pretexto de que a música acontece no tempo, representa ela igualmente a imagem do transcorrer do tempo? Digamo-lo de outro modo: a música, "graças à presença de certos de seus atributos ou características dinâmicas e formais", nos permite acessar a experiência do tempo, em outras palavras, "de acessar aquele nível mais profundo que a razão ela própria não é capaz de alcançar" (para este parágrafo, ARBO, 2010, p. 295)? É trazendo-se uma resposta àquela questão que será possível precisar em que consiste a narratividade substância - aquilo que fizemos em três etapas: o tempo não é um sujeito; o tempo está em nós; a narratividade é primeira, no som, e não enquanto tempo.

\section{O tempo não é um sujeito}

Ele não é, pois não é isso ou aquilo:

as dificuldades surgem quando nos debruçamos sobre um 'tempo' que se apresenta enquanto sujeito da ação ou fenômeno que pretendemos explicar. Esse uso, observava Wittgenstein, pode 'nos dar a ilusão de um medium'. Acabamos assim por nos perder e 'correr em todas as direções atrás de um fantasma'. (ARBO, 2010, p. 297). 
É o risco ligado àquilo que Wittgenstein chama a "personificação do tempo" (ibid., p. 296), que faz deste um "movimento originário isento de toda descontinuidade", então mesmo que " não possamos comparar nenhum processo com o decorrer do tempo", pela simples razão de que ele não existe como um "fato" no nosso "mundo" (ibid., p. 295-296). Por consequinte, mesmo se "a música expõe uma dinâmica e uma temporalidade próprias, suscetíveis de serem comparadas àquelas de outros processos temporais", "parece mais difícil explicar em que sentido ela pode se referir a um tempo mais profundo e originário do qual ela seria a simples ilusão primária" (ibid., p. 297).

De fato, essa declaração implica que já saibamos aquilo que é exatamente essa temporalidade (de outro modo, como poderíamos saber que se trata de uma ilusão?). E o problema é justamente este: como podemos afirmar a presença dessa temporalidade? Temos certeza de tê-la vivenciado em em algum momentto, e de não nos termos enganado (é sabido que nossa vida é frequentemente 'tomada' a partir do tempo do relógio)? E como fizemos, po sinal, para identificar este 'fluir' do tempo puro e contínuo? Poderíamos responder com Bergson que é a nossa consciência direta que o atesta, por simples intuição. Mas, ao olhar mais de perto, nossa consciência não é capaz de atestar o que quer que seja, em primeiro lugar porque ela não poderia o verificar sem recorrer a signos cuja significação não seria dedutível por simples introspecção e, em segundo lugar, porque tal verificação não teria mais sentido para ela (ibid., p. 297-298).

Consequentemente, a música não é redutível a nenhum dos dois fantasmas frequentemente invocados: um tempo original, puro, contínuo; o tempo cronométrico (ibid., p. 299). Donde o segundo ponto: se o tempo não é externo a nós, de algum modo imposto por uma instância que nos antecede e nos excede, é que ele está em nós. 


\section{O tempo está em nós}

"Não existe melhor lugar do que ser nômade onde estamos". Essa frase atribuída a Gilles Deleuze é uma das pontas de lança da filosofia de Daniel Charles. No artigo ao qual nos referimos aqui, essa expressão conclui uma demonstração que visa esclarecer a verdadeira natureza do tempo (para o desenvolvimento que segue, cf. CHARLES, 2009, p. 8-10). Daremos conta dessa demonstração em três tempos. Em primeiro lugar, com uma máxima de Rivarol, um ensaísta do séc. XVIII: "O movimento entre dois repousos é a imagem do presente entre o passado e o futuro. O tecelão que faz sua teia faz sempre o que não é". Em seguida, com o que diz Deleuze a respeito, a partir de Heidegger:

Considerando a repetição dentro do objeto, ficávamos abaixo das condições que tornam possíveis uma ideia de repetição. Mas, considerando-se as mudanças dentro do sujeito, estamos já além, diante da forma geral da diferença. Também a constituição ideal da repetição implica um tipo de movimento retroativo entre esses dois limites. Ela se tece entre os dois.

Enfim, como se manifesta a propósito Beda Allemann, a partir de Heidegger: "Não é o tempo que se move ('se desenrola'), mas nós, enquanto atuando no presente (o tecelão), realizamos um movimento de vai-e-vem entre o passado e o futuro".

\section{E acrescentando:}

É necessario observar a estranha colocação de Rivarol 'O tecelão... faz sempre o que não é', o que equivale a afirmar que sua ocupação, quando fabrica o tecido, é o não-existente. A pro-dução ela própria (no sentido amplo de poiesis) não é, no sentido do ser neutro do existente, mas aparece sob a forma de um vai-e-vem 
'entre dois repousos' que são as dimensões da proveniência e do devir.

É nesse sentido, portanto, que o tempo está em nós. Ele está, neste movimento perpétuo entre o que não é mais e o que não é ainda. É por esta mesma razão que somos o sujeito do tempo, e não o inverso, pois está em nós assegurar este movimento, de continuá-lo, nada nem pessoa alguma podendo fazê-lo em nosso lugar. - Por consequinte, não é o tempo que acolhe a música, mas a música que, através nós, acolhe $o$ tempo. E, paradoxalmente, é agora que nós libertamos da questão do tempo que podemos abordar a questão da narratividade. Donde o terceiro ponto.

\section{A narratividade primeira está no som}

Nos apoiaremos em outro texto de Daniel Charles, com o título explícito: "Música e narratividade: a escrita do ruído" (CHARLES, 2001, p. 99-110). Esse "ruído" está inevitavelmente presente em toda música, posto que se trata da essência do som ele próprio, mais precisamente: do timbre. Este não pode jamais ser completamente domesticado, neutralizado (e a voz, com seu grão, o sopro, representa possivelmente o melhor exemplo). Para Daniel Charles, existe portanto uma narratividade própria ao som, ao ruído. Para sustentar sua demonstração, ele examina como as "músicas clássicas", de um lado, e a música do séc. XX, de outra, trataram o timbre, em que medida elas the deixaram a palavra.

As "músicas clássicas" ensaiaram domesticar o timbre, que elas consideraram como ruído. E o sistema tonal se defendeu "pelos meios da tangente". O que significa que "as interferências, sons parasitas, acordes 'não classificados', cromatismos invertidos, em resumo os ruídos ou os 
timbres, são colocados desde sua abordagem como não existindo". Entretanto, "nenhum som ouvido ressoa sem seu timbre", e "separar desse timbre a linha das alturas supõe uma focalização feroz", uma rejeição "daquilo que nos conta o som". E para "justificar o exílio dessa estória", substituimos portanto "o tempo dos sons pelo tempo das relações" (para este parágrafo, cf. CHARLES, 2001, p. 108-109). Mas o material não o entende assim : ele resiste a essa "amputação" de seu "teor sensível' (ibid., p. 108). Pois "jamais existiu música 'pura”, e "nunca elaboramos nada que não fossem ilhas ou ondas de racionalidade - como se o ruído de fundo tivesse sido tematizado apenas para melhor ocultar o ruído da forma" (ibid., p. 101, grifo nosso).

Com o século XX, mudam as coisas. O material é liberado. A "pluralidade competitiva dos parâmetros é reconhecida", e é então o "retorno deste reprimido que é o ruído" (ibid., p. 110). Com a "melodia de timbres" de Schoenberg, a seguir com Webern, e sobretudo com Debussy, o timbre torna-se, ou volta a ser, "o elemento essencial da música": o desenrolar temporal não é mais linear mas vertical, e Ihe reconhecemos assim "uma espessura inédita e entretanto primordial"; os timbres não são mais utilizados "para ilustrar", numa narrativa de superfície, um discurso frequencial prévio, mas inversamente [...], um recitar/recital/recitativo de trimbres por inteiro, primeiro"; "os direitos da palavra viva contra o código" são assim restabelecidos, "os do som contra a nota" (para este parágrafo, cf. ibid., p. 106-107). O timbre exprime assim, em sua própria materialidade, uma narrativa primeira, irredutível, que Daniel Charles nomeia "ruído da forma".

Pois a narratividade, cessa de ser "controlada 'pelo exterior' do tecido musical, ela já penetrou [...] todo o corpo da música", e a música, assim, "faz ressoar, em um murmúrio ininterrupto, o rumor do mundo, o burburinho próprio do l'il y a" (ibid., p. 110). 
É portanto a isto que corresponde esse fluxo da narratividade musical que chamamos de substância. É o ruído primeiro, o ruído da forma, que murmura de todos os ruídos - e ao mesmo tempo do silêncio - do mundo. O que é composto, o ruído de fundo, portanto a música, compõe primeiramente com essa substância, este ruído de forma, que é o timbre.

\section{A narratividade de moldura}

O segundo fluxo da narratividade corresponde ao tempo tal como é construído, e mais precisamente problematizado, numa obra, um conjunto de obras, um estilo. Essa narratividade que nós chamamos de "moldura" remete a uma concepção dada do tempo e que, sobretudo, é primeira. É em função dela, por exemplo, que o timbre é tratado de uma maneira ou de outra. Mesmo John Cage liberta o som apenas para que liberte o tempo, ou, para afirmá-lo de outro modo, ele libera o tempo no liberar o som. Ele compõe conforme "a natureza do som, é o mesmo que dizer conforme o tempo" para, no final das contas, "reencontrar um veio temporal mais profundo" (CHARLES, 2001, p. 108), e instaurar assim outro tempo. Diremos que este tempo, que corresponde à narratividade que emoldura, é o tempo tal qual ele é vivido numa certa época, num certo lugar, dentro de um certo contexto coletivo e individual. Dito de outro modo, este tempo vivido não é vivido como se fosse uma resposta a uma problemática particular. Para Michel Imberty, essa problemática está ligada ao que chama de "a ambivalência do tempo".

Esse conceito não pode ser dissociado daquele relativo à "ligação" que, ele próprio, remete à distinção entre "tempo contínuo" e "tempo descontínuo". Para Michel Imberty, a experiência humana é marcada pela consciência do caráter irreversível do tempo, em que cada instante leva inexoravelmente ao envelhecimento e, finalmente, à morte (2004 [2002], 
p. 400). É isto mesmo que é designado pela expressão "ambivalência do tempo". Uma ambivalência que se pode aceitar, ou não. Ao aceitá-la, nos pomos na condição "de construir ligações entre os objetos, as pessoas", "de construir objetos simbólicos" e "de conceber relações entre o passado, o presente e o futuro" (ibid., p. 409). Ao não aceitá-la, torna-se impossível a ligação: "toda percepção torna-se fragmentária, todo sentimento de duração é inexistente, toda forma de linguagem, impossível" (ibid., p. 410).

Donde a distinção, de uma parte, entre o universo clássico e romântico, que aceita a ambivalência do tempo e que cria portanto um tempo contínuo; de outra parte, o universo contemporâneo, que não a aceita e que cria, por consequência, um tempo descontínuo. O que, sobre o plano musical, e para permanecer a considerações muito gerais, remete à seguinte distinção: entre a música tonal, na qual a forma cria a "ligação", "domina o caos interior e o tempo existencial no seu devir" (ibid.); e a música pós-Debussy, na qual "a falta de ligação temporal [...] equivale [...] a uma desintegração da experiência do tempo existencial que exclui todo pensamento e toda representação do horizonte futuro e mortal" (ibid., p. 411 ; cf. 400-401 e 406-408 para Debussy). Em outras palavras, num caso, a música tonal, o tempo musical é contínuo; na música que se segue a Debussy, o tempo musical é descontínuo (cf. IMBERTY, 2003 [2001]): "uma forte hierarquização através o encaixamento das unidades provoca no ouvinte um forte 'sentimento de continuidade', ao invés uma fraca hierarquização estrutural onde dominam as justaposições que fragmentam o tempo musical engendra no ouvinte um forte 'sentimento de descontinuidade' e de imprevisibilidade da forma" (ibid., p. 633).

De onde a conclusão de Michel Imberty: 
Em definitivo, a música bem poderia aparecer como um simbolismo do tempo existencial, coletivo ou individual, e o estilo de uma obra musical testemunharia das atitudes inconscientes fundamentais do homem frente à irreversibilidade do devir, do envelhecimento e da morte, refletidos através a sensibilidade de uma época e a imaginação criativa de um artista de gênio (2004 [2002], p. 402).

Em poucas palavras: "[o] estilo é, portanto, uma forma do tempo" (IMBERTY, 2003 [2001], p. 663; 2005, p. 66), quer dizer "uma qualidade de organização particular do tempo musical, uma qualidade do devir e da duração através da distribuição dos eventos sonoros dentro do tempo linear" (IMBERTY, 2005, p. 66). O que significa que o fluxo da narratividade e o que chamamos de "moldura" pode ser assimilado, dentro de uma certa abordagem, ao estilo considerado como escrita do tempo, para parafrasear o título de um trabalho de Michel Imberty (1981). Ou ainda, conforme seus próprios termos, ao "esquema de estruturação do tempo" próprio de uma obra ou de um estilo (2005, p. 64), esquema também chamado de "macroestrutura" (ibid.), "ou representação mental da progressão temporal da obra musical" (ibid., p. $65)$.

Esse conceito pode ser definido como um esquema de estruturação do tempo, quer dizer, como a redução das estruturas temporais de tensão e repouso da peça, ou se quiserem ainda, uma representação mental da progressão temporal da obra musical. Dito de outro modo, antes de ser uma hierarquia estrutural gramatical, uma peça musical é antes de tudo uma ordenação de eventos sonoros dentro do tempo, e sua macroestrutura, um tipo de esquema simplificado, uma ordenação a priori que em seguida vem preencher os acontecimentos sonoros concretos cuja progressão para o ouvinte parece mais ou menos contínua, linear ou sinuosa, regular ou caótica. Essa progressão é evidentemente de natureza puramente dinâmica, ela induz uma orientação mais ou menos perceptível e analisável, identificável na sua globalidade, aleatória no seu detalhe; em suma, ela desenha para o ouvinte, como sem dúvida ela se impôs ao compositor, um arco sensível irreversível e contínuo do tempo (ibid., p. 64-65). 


\section{A narratividade intriga: o que a fundamenta}

É o terceiro e último fluxo semiótico da narratividade musical que examinaremos neste estudo. O primeiro destes fluxos - a narratividade substância - corresponde àquilo que Daniel Charles chama "ruído da forma" (e não "ruído de fundo", justamente), quer dizer, aquilo que é primeiro, aquilo que já é e que estará sempre ali, a saber, o rumor, o murmurinho do mundo, do qual participam (dentre outros) o timbre, o sopro da voz, o silêncio. O segundo destes fluxos - a narratividade moldura - corresponde a uma certa problematização - ou préconfiguração - do tempo, ou ainda, conforme os termos de Marcel Imberty, a um "esquema de estruturação do tempo", ou simplesmente a um "estilo". O terceiro destes fluxos - portanto a narrativa intriga corresponde à obra tal como ela se desenvolve no tempo, "ruído de fundo", conforme Daniel Charles, pois ela compõe com aquilo que já pertence ao mundo, aquilo que já está sempre lá.

Diversos pontos necessitam serem definidos.

(1) Essa narratividade intriga não existiria sem as duas outras. O inverso não é verdadeiro: elas existem, mas sem poder fazer obra por si mesmas, nem mesmo juntando-se as duas. De fato, é somente através a associação destes três fluxos de narratividade que é possível fazer uma obra: uma substância, um tempo, uma intriga.

(2) Esse conjunto não pode portanto existir sem uma intenção composicional (mesmo uma mínima, como em algumas obras de John Cage, por exemplo), que institui uma obra. 
(3) O que nos interessa aqui não é essa intenção composicional, mas sim o fluxo narrativo, quer dizer, a intriga tal como ela é percebida pelo ouvinte (no sentido amplo). Mais precisamente, a intriga do ponto de vista de sua percepção em tempo real, de sua cronologia. Pois o objetivo é o de demonstrar quanto "à natureza incerta, tateante, passional e irredutivelmente temporal de toda experiência estética" (BARONI, 2010, p. 203). Dito de outro modo, o tecelão em sua obra, no seu "vai-e-vem 'entre dois repousos'” (ALLEMANN apud CHARLES, 2009, p. 9).

(4) Dizemos claramente leitor e não receptor. Trata-se do processo de atualização operado por um leitor, e não de uma resposta a questões ligadas a um se-compreender hermenêutico, ainda que este não se encontra muito longe (para uma abordagem cognitiva da narratividade musical, cf. HAUER, 2015).

(5) Chegamos assim, para além do primeiro objetivo que era a apresentação dos três fluxos semióticos da narratividade musical, ao outro objetivo anunciado na apresentação deste artigo: propor uma abordagem narratológica da narratividade intriga, quer dizer, da obra musical tal como ela é atualizada por um leitor.

\section{A " feitura da intriga"}

Apresentaremos inicialmente três princípios básicos.

(1) A música é narrativa, pois se escreve, se lê, se toca e se escuta como uma sucessão ordenada no tempo. Traremos à nossa tarefa - para a música - a definição que propõe Jean-Marie Schaeffer da narrativa como "sempre temporalmente orientada e compelida pelas normas de 
coerência sequencial ou casual", como "tipo de discurso cuja início e conclusão são determinados de maneira interna, pela dinâmica própria do tipo de encadeamento que a organiza", enfim, como "forma discursiva que dispõe de um princípio de completude interna" (SCHAEFFER, 2010, p. 217$)$.

(2) A música é narrativa, mas não poderia sê-lo sem um tomar ou um captar-junto. Pois o ouvinte seria sem isso submisso a um fluxo de informações inorganizável(veis). Esse fio-condutor corresponde ao caráter configuracional da trama, que permite realizar um todo significante a partir de elementos sucessivos e diversos: uma "concordância discordante, característica de toda composição narrativa", que Paul Ricœur designa "pela noção de síntese do heterogêneo" (2013, p. 82). Em consequência:

A feitura da intriga inclui portanto ao mesmo tempo uma dimensão cronológica ou episódica que incita o leitor ou ouvinte a se perguntar como prosseguirá a estória (as 'referências que indicam para a frente' de Mink) e uma dimensão não-cronológica ou configuracional, um ato de compreensão ou de 'captar-junto' configuracional (que Ricœur relaciona com o julgamento refletido em Kant) que transforma os eventos numa totalidade significante tendo um 'proposto' ou um 'tema' e um sentido de conclusão (um efeito sintético, mais do que referências que apontam para trás) (PIER, 2010, p. 175).

(3) Mas isso não é o suficiente. De onde o terceiro princípio determinante: somente a tensão torna possível a feitura da intriga. Pois "é bem a tensão que ritma a intriga ao contrastar seus tempos 'fortes' (ou tônicos) e seus tempos 'fracos' (ou átonos) e, de novo, é a intriga que configura temporalmente a tensão, que lhe dá sua 'extensão' e sua 'direção' (BARONI, 2007, p. 52. Cf. 2010. Para uma aplicação à música 
do conceito de tensão narrativa, cf. BARONI, 2011; GRABÓCZ, 2011). É o jogo da tensão e sua resolução que faz o ouvinte ser interessado, surpreendido, preso pela trama - que ele é propriamente intrigado. É o que Gabriel Sevilla chama de 'tensão télica', que ele aplica à música e que define como "a imersão cognitiva do emissor e/ou do receptor no desconhecido relativo às intenções de um sujeito, agente ou paciente, frente à um fato que ainda não aconteceu" (SEVILLA, 2014).

\section{O conceito de "tensão narrativa"}

Esse conceito forneceu seu título ao trabalho de Raphaël Baroni publicado em 2007: "A intriga, antes de se referir à trama de uma história, deve ser assim redefinida como um dispositivo intrigante que permite amarrar o sujeito introduzindo, durante a progressão dentro da estória, uma tensão narrativa" (BARONI, 2011). Para Jean-Marie Schaeffer, as principais questões do "modelo" proposto por Baroni são duas. De um lado, o destaque da "dinâmica da tensão narrativa e de sua resolução", aquilo que se traduz no leitor (e sem dúvida mais ainda no ouvinte) "pela tensão entre a disforia apaixonante, que mantém vivo seu interesse, e a euforia, que resulta da resolução da tensão produzida pelo suspense ou pela curiosidade". Por outro lado, o fato de considerar não somente "o polo de atividade autoral (a trama)" $e$ "aquilo que é a atividade do receptor", mas também "a atividade que os coloca em relação, a saber, o jogo de funções tímicas”, como o suspense, a curiosidade ou a surpresa (SCHAEFFER, 2007, p. 14).

Podemos distinguir no mínimo dois aspectos dessa "poética da intriga" (BARONI, 2007, p. 27). 
(1) As diferentes fases da intriga, em número de três, que constituem as "dobras principais da história", e que são "sucessivamente atualizadas" pelo leitor (para a descrição das três fases, salvo indicação contrária, cf. BARONI, 2007, p. 122-123).

Primeira fase: o "nó". Junto a uma "incompletude provisória do discurso", um questionamento se produz, "que é como um gatilho da tensão". Em poucas palavras, a função do nó é de intrigar. Segunda fase: o "atraso". Ele constitui a "fase de atenção": fonte de incerteza e de antecipação (dentro da perspectiva do desfecho esperado), ele provoca por essa mesma razão "uma maior participação cognitiva" (BARONI, 2007, p. 99). É uma fase essencial, pois sem essa expectativa da resolução, ou do desfecho, "a tensão narrativa não é configurante", do fato mesmo que "ela não polariza a estória" e "não orienta a temporalidade do discurso" em direção ao desfecho que segue. Este caráter configurante da expectativa associado à tensão é particularmente crucial em música, como Leonard B. Meyer (2011 [1956]) e David Huron (2006), entre outros, demonstraram. Terceira fase: o "desfecho". Ele traz a resposta, e por este mesmo caminho resolve a tensão.

Dito de outro modo, para que haja estória, narração, é necessário uma intriga (trama); para que haja esta, é necessário uma tensão; para que haja uma tensão, é necessário um nó (laço) e um desfecho.

(2) A sucessão das diferentes fases da trama constitui a dimensão retórica, ou estratégica, da tensão narrativa. Com este objetivo, atuam duas figuras dinâmicas, ambas ligadas a uma expectativa, uma incerteza, uma antecipação incerta. Por um lado, uma função tímica, que remete àquilo que experiencia o leitor, e que por sinal corresponde seja ao "suspense" (em caso de "atraso estratégico da resposta"), seja à 
curiosidade (em caso de representação incompleta da ação). Por outro lado, uma função cognitiva, que faz apelo às competências do leitor, e que na circunstância corresponde seja ao "prognóstico" (ligado ao suspense), seja ao "diagnóstico" (ligado à curiosidade) (para esse parágrafo, cf. BARONI, 2007, p. 99-100; 107-111).

Para sintetizar:

Toda a nossa empreitada terá sido a de finalmente na ordem do dia, para retomar os termos de Derrida, a força que se dissimulava por trás da forma da intriga, colocando a obra na relação interlocutiva e recronologizando o ato de leitura. Mostramos que a organização da estória em sequências depende disso que chamamos, desde Aristóteles, o fenômeno da 'trama', e que esse processo repousa essencialmente, se o substituirmos no contexto de interação discursiva, sobre uma incerteza, sobre uma indeterminação constituída pelo discurso, sobre uma estratégia textual tensiva que visa à intrigar o destinatário de uma estória ao atrasar a apresentação de uma informação que ele desejaria conhecer de imediato. Colocamos em evidência duas formas fundamentais de textualização da sequência narrativa realizando esta estratégia retórica, duas 'figuras dinâmicas' que permitem, dentro do contexto da narratividade, amarrar uma trama, e que estão ligadas inteiramente às questões relativas ao entender cognitivo das (inter)ações: quer a informação atrasada endereça-se sobre o desenvolvimento ulterior de uma série de eventos cujo resultado permanece até o fim incerto (desde sempre, a relação cronológica gera um suspense); quer seja trate-se da compreensão de um evento atual ou passado que é provisoriamente impedido (se trata neste caso de uma feitura da trama através a curiosidade) (BARONI, 2007, p. 399-400).

\section{A narratividade intriga : algumas condições essenciais}

O conceito de tensão narrativa coloca o leitor (entre os quais se inclui o ouvinte) como ator central do processo. Donde a insistência, por Raphaël Baroni, sobre "a função interacional da intriga" e "a dinâmica de 
sua percepção" pelo ouvinte (2011). É portanto "impossível tratar a tensão narrativa sem levar em consideração a participação cognitiva e efetiva do leitor na percepção do texto" (2010, p. 202). Deste ponto de vista, Raphaël Baroni reivindica a herança das teorias da recepção ligadas ao " efeito visado pelo texto", quer dizer, "à maneira cumo o texto visa a ser atualizado" (2007, p. 28; cf. p. 91-100: "3.1 Suspense e curiosidade nas teorias da recepção"). Ele se inscreve, em consequência, "na moldura de uma 'recepção modelo'", e não procura "descrever a atualização mais ou menos pessoal que produz efetivamente um determinado intérprete" (2007, p. 27). É por este motivo que utilizamos aqui o termo "leitor" ao invés de "receptor", que é mais pertinente ser reservado a uma hermenêutica da recepção musical, notadamente inspirada em Paul Ricœur, que interroga o porquê desst ou aquela recepção, do ponto de vista de se compreender diante da obra, seja a partir de um receptor particular, seja de uma comunidade de receptores (cf. HAUER, 2007; 2009).

É essa concepção de "tensão narrativa" que propomos retomar, pois trata-se, a nosso ver, de uma ferramenta potente de investigação no campo da significação - e portanto da semiótica - musical. Dentro do escopo deste artigo, insistiremos sobre a necessária interação entre um leitor (-ouvinte) e um texto (musica). Examinaremos alguns dos fatores que intervêm dentro dessa interação, que, sem isso, não poderia acontecer: a intencionalidade, do ponto de vista das intenções do autor, a empatia, do ponto de vista da embodied simulation (ou simulação incarnada); a intensidade, do ponto de vista das formas de vitalidade. 


\section{Interação 1: a Intencionalidade}

Para Jean-Marie Schaeffer, "o princípio da intencionalidade faz parte do processo de compreensão" (2011, p. 90; sobre a questão da intencionalidade, cf. p. 88-91). Isso significa que temos que nos interrogar sempre sobre aquilo que o autor quer dizer quando observamos, escutamos ou executamos uma obra de arte. Com efeito, percebemos inevitavelmente toda obra de arte como resultado de uma procedimento intencional: "um evento físico, tal como a emissão de um grupo de sons ou de grafemas, constitui um ato de linguagem apenas se exprime um estado intencional" (ibid., p. 89). Se Jean-Marie Schaeffer toma como exemplo, a leitura, o mesmo vale para todas as formas de expressão artística:

Trata-se simplesmente da regra constituinte da compreensão e da significação. Ler (quer dizer, compreender aquilo que se lê), é dotar uma cadeia de signos gráficos de uma significação, é constituí-la em expressão de um conteúdo intencional, que só estados e atos mentais podem possuir (ibid., p. 90).

Uma definição importante: a questão aqui não é "das intenções reais do autor histórico", mas das "intenções hipotéticas do autor postulado" (DARSEL, 2010, p. 254) (2). Quer dizer, as intenções que atribuímos ao autor, sobre a base daquilo que a obra propõe, nos diz, mas também daquilo que sabemos - ou cremos saber - de uma obra, de seu autor ou ainda do contexto de sua produção. Mais precisamente:

A dificuldade, ver a impossibilidade, de destacar o sentido intencional da obra não tem contudo nada de dramático. 'O que significa o texto?' e 'qual é o projeto dando origem ao texto?' são duas questões não somente diferentes, mas independentes. [...] Certamente, todo leitor busca espontaneamente reconstituir a partir do texto que está lendo uma figura de enunciador; mas esse reflexo inerente a toda situação de comunicação (e que não é forçadamente coroada com sucesso) não implica de modo algum que seja 
necessário documentar-se a respeito do projeto do autor. É preciso não confundir 'ler buscando revelar uma intenção' (o que todo mundo faz) e 'ler depois de ter identificado um projeto'. Somente os eruditos e os leitores 'profissionais' (professores, historiadores da literatura, estudantes) leem dessa segunda forma (JOUVE, 2010, p. 70-71; cf. p. 83-84; p. 104).

Para tratar desta questão da intencionalidade, tomaremos como referência um trabalho publicado em 2012, A obra de arte e suas intenções, de Alessandro Pignocchi, para quem a questão não é mais saber se é necessário levar em conta as intenções do criador - no sentido das intenções reais - mas se levarmos necessariamente em conta - no sentido das intenções atribuídas (2012, p. 13-15; cf. 2015). Apoiando-se nos trabalhos recentes em ciências cognitivas, Alessandro Pignocchi propõe e desenvolve um "modelo intencional", que mostra que "nossa inteira relação com a obra de arte se organiza em torno das intenções que atribuímos ao artista" e de uma construção mental em geral inconsciente e implícita de seu procedimento (ibid., p. 110; p. 177178), ao ponto que "mesmo que quiséssemos fazer abstração de toda imputação de intencionalidade, não o poderíamos" (SCHAEFFER, 2012, p. 10). Dentro do escopo desse modelo, o termo "intenção", deve ser entendido num sentido muito amplo, cobrindo toda "a variedade de estados psicológicos que somos capazes de atribuir a outrem", "todos os estados mentais - as ideias, as emoções, as intuições, os traços de caráter,etc. - que puderam executar um papel casual na produção da obra" (PIGNOCCHI, 2012, p. 117-118; cf. p. 135-136). Dito de outro modo, somos sempre - o mais frequentemente sem nos darmos conta levados a nos perguntar, diante de uma obra de arte, aquilo que o autor quis fazer, dizer, exprimir.

E isto, pela razão seguinte: 
as propriedades de uma obra são imediatamente organizadas e segmentadas por nosso sistema perceptivo sobre a base das hipóteses implícitas ligadas à atitude do artista: as propriedades da obra foram pensadas para resolver certos problemas, elas são em parte o resultado da intenção que eu mesmo poderia ter formado, elas são índices dados pelo artista para que eu possa reencontrar aquilo que ele quer me fazer compreender (ibid., p. 217).

Com efeito, a percepção e a ação estão indissociavelmente ligadas uma a outra, "[nossa] percepção é organizada, que o queiramos ou não, pela representação que construímos progressivamente pela prática", em outras palavras por nossas atividades passadas que forjaram competências e os conhecimentos específicos, tais como desenhar ou ainda contar estórias; o que explica que, de um lado, não podemos compreender os desenhos que nos mostram e as histórias que nos contam apenas porque sabemos nós mesmos desenhar ou contar estórias, e que, de outro lado, os compreendemos porque aparecem por estas mesmas razões próprias como "o fruto de intenções que nós mesmos poderíamos ter formado" (ibid., p. 170-174).

É neste sentido que, na nossa experiência da obra, as intenções atribuídas - do criador se associam ao centro mesmo de nossa interação com esta obra.

\section{Interação 2: a embodied simulation (ou simulação incarnada)}

"Simulação corporificada" ou "incarnada", tal é a tradução literal do termo "embodied simulation". Ela dá bem conta deste fenômeno: alguma coisa que incorporamos a a nós mesmos, literalmente que encarnamos, simulando-o, no sentido de imitar. Na literatura científica são igualmente utilizados para designar mais ou menos o mesmo fenômeno, termos como "empatia", "contágio emocional" ou ainda 
"mimetismo". De qualquer modo, a ideia básica é que a música "está enraizada no corpo" (cf. IMBERTY, 2013). Proporemos a seguinte definição de embodied simulation: "um mecanismo funcional que faz com que as ações, as emoções ou as sensações que observamos ativam nossas próprias representações internas do estado de corpo que estão associadas a esses estímulos sociais, como se estivéssemos engajados numa ação similar ou como se experimentássemos uma emoção ou sensação semelhante" (FREEDBERG \& GALLESE, 2007, p. 198). Dito de outro modo, entendemos aquilo que percebemos simulando-o graças ao que conhecemos, e isto, por já tê-lo experimentado.

De sua parte, Gabriel Sevilla utiliza o termo "tensão patética", que define "como a imersão cognitiva do emissor e/ou receptor dentro do pathos (emoção e sensação) de outrem, simbólico ou real, adotando sua perspectiva" (SEVILLA, 2014). Ele insiste sobre a "imersão cognitiva da empatia" como "modalidade mais intensa, mas não exclusiva, da tensão patética", e acrescenta que uma "certa ideia de tensão" participa dessa empatia, na medida em que esta supõe "uma reação obrigatória ao estímulo inicial" (ibid.). E ainda cita Simon Baron-Cohen, para quem "existem ao menos duas etapas na empatia: reconhecimento e resposta" (ibid.).

Imersão e reconhecimento, de um lado, reação e resposta, de outro: muitos elementos dos quais depende a possibilidade mesmo de uma interação com a obra. E essa interação passa necessariamente pelo corpo.

Para precisar em que consiste tal interação no caso da música, tomaremos como referência um estudo publicado em 2011 por Arnie Cox: "Embodying Music: Principles of the Mimetic Hypothesis". Essa 
hipótese mimética trata da maneira pela qual a música é interiorizada no corpo e no espírito do ouvinte: compreendemos a música a partir de um tipo de empatia física que faz com que imaginemos produzir os sons que ouvimos. Trata-se exatamente do fenômeno também chamado de embodied simulation (ou simulação incarnada). Com efeito:

A hipótese mimética aborda a questão do embodiment ao mostrar como a imagem musical (musical imagery) - lembrança, antecipação ou ainda pensar além da música - revela em parte uma imagem motriz. A imagem motriz é uma imagem ligada aos esforços e aos movimentos produzidos por nosso sistema esquelético-motor, e no caso da música isto também implica nos esforços suscitados pela performance musical. A hipótese mimética precisa como isto poderia funcionar e indica como isso poderia subjazer à conceituação e ao sentido. O postulado de partida da hipótese é que parte da maneira como compreendemos a música corresponde a um tipo de empatia física que consiste em imaginar que produzimos os sons que ouvimos. É um caso particular da propensão humana compreender outrem por imitação, o que podemos associar a uma cognição mimética ou a uma compreensão mimética, quando o termo 'mimética' é usado da maneira indicada abaixo; donde a 'hipótese mimética' (COX, 2011).

A partir deste fato, Arnie Cox apresenta - apoiado em numerosos exemplos - os princípios da "hipótese mimética", em número de 18 :

\section{Preliminar: o som e suas fontes}

1. Os sons são produzidos por eventos físicos: os sons indicam (significam) suas fontes físicas.

2. Muitos ou a maioria dos sons musicais são a evidência das ações motoras humanas que os produzem. 


\section{O comportamento mimético e a imagem em geral}

3. Os seres humanos compreendem outros entidades (animadas ou não, humanos ou não) e os eventos no seio de um ambiente em parte por imitação explícita ou implícita.

4. A imitação explícita e a imitação implícita constituem representações corporais das ações observadas.

5. Os seres humanos compreendem o comportamento de outrem em parte pelo comportamento mimético e pela MMI ("mimetic motor imagery").

6. As ações imaginadas são informadas pelas ações efetuadas.

7. A imitação pode ser intencional, consciente e frequentemente não consciente.

8. A imitação é mais fortemente ativada na observação das ações dirigidas para um objetivo.

\section{Os princípios mais específicos à música}

9. A ação mimética e a MMI se produzem em tempo real e em "lembrança" (e possívelmente na "planificação").

10. A imagem motriz mimética e a ação se produzem segundo três modalidades: intra-modal, intermodal, e amodal. 
11. Todas as características acústicas podem ser ou serão representadas por mimetismo.

12. Diferentes tipos de música "convidam" a diferentes tipos de engajamento mimético.

13. Certas músicas atenuam o convite mimético.

14. A música de conjunto oferece mais "convites".

15. As respostas miméticas são frequentemente mais fortes nos contextos live que nos gravados.

16. A MMI varia em força e precisão conforme os indivíduos.

17. A MMI motiva e limita a conceituação (metafórica ou outra).

18. O comportamento mimético e a MMI implicam a participação mimética, a comunicação, e o afeto.

Assim, segundo o décimo princípio, este fenômeno da empatia se manifesta conforme três formas distintas (mas que podem ser associadas): (a) uma forma intra-modal, o exemplo do movimento de dedos do ouvinte imitando o executante; (b) uma forma amodal, o exemplo da imitação abdominal do esforço demandado para se produzir sons; (c) uma forma inter-modal, a exemplo da imitação subvocal dos sons instrumentais (COX, 2011).

Em música, o fenômeno mimético, ou de simulação incarnada, é particularmente dominante. Pois a música é necessariamente tocada (ou 
cantada): há sempre alguém que faz, um ou dois executantes. Certamente, a noção de execução parece em certos casos perder em pertinência (músicas eletrônicas ou eletroacústicas, músicas geradas em rede pela internet,...) . O que não impede que a música seja, de um lado, uma produção (que nós chamamos ou não de obra), quer dizer, um artefato feito intencionalmente - mesmo que de maneira aleatória - por uma ou mais pessoas, e, de outro, vibrações sentidas de maneira empática - ou mimética - e ligadas a uma fonte sonora mais ou menos identificável. A figura do executante - no sentido mais amplo - está assim presente físicamente em toda música ouvida, incluindo-se naquela gravada. Isso nos leva a propor a seguinte hipótese: que o executante em música aparece como um narrador, dentro da acepção narratológica do termo, e, em tal modo, como local do sentido (HAUER, 2014).

A música suscita - provoca - portanto permanentemente a experiência de embodied simulation. Não somente entre os executantes - os narradores - e os ouvintes, mas também entre os próprios músicos: os músicos que tocam - e ainda mais improvisam - juntos constituem um exemplo impressionante de simulação incarnada em ação. Entretanto, outro fenômeno ainda opera neste caso: as formas de vitalidade.

\section{Interação 3: as formas de vitalidade}

Para definir esse conceito, Daniel Stern propõe uma lista de palavras, como: "explodir", "dilatar", "distender", "acelerar", "potente", "imóvel", "tenso", "efêmero", etc. (2010 [2010], p. 17).

Eis o que ele afirma: 
Ainda que estas palavras sejam relativamente comuns, é uma lista curiosa. A maior parte desses termos são verbos ou adjetivos. Não se trata de emoções, estados de motivação ou percepção puros. Não são tampouco sensações no sentido explícito, porque destituídos de modalidade. Não são estados cognitivos no sentido habitual. E não se trata de atos, porque não têm objetivos nem meios específicos. Essas palavras passam por todas as malhas da rede. Elas denotam uma experiência sentida de força (em movimento) diante de um perfil temporal (e uma energia) dirigida para algo. Elas não se relacionam a algum conteúdo particular. Elas são mais formas que conteúdo. Elas dizem respeito ao "como", à maneira, ao estilo, e não ao "quê" ou o "porquê". Independentemente do 'conteúdo' (pensamentos, atos e emoções), esta Gestalt de vitalidade curva-se a si mesma (por exemplo, acelerar, explodir, declinar). Ela constitui um tipo de experiência distinta. Para mim, as formas de vitalidade dinâmica são as mais fundamentais de todas as experiências que possamos ressentir no escopo de uma interação com outras pessoas em movimento (ibid., p. 17-18; grifo nosso).

Para Michel Imberty, as formas de vitalidade são "sentidos". Elas são "de natureza dinâmica e temporal", "conferem espessura ao momento, ao presente da ação ou à emoção em curso", correspondente às "maneiras de sentir, estar com, antes mesmo de serem emoções ou sentimentos particulares" (IMBERTY, 2005, p. 195).

A partir deste fato, no escopo da interação que se dá entre o leitor e o texto no seio da experiência artística, distinguiremos duas funções principais das formas de vitalidade: uma assegura a intensidade dessa interação, a outra, o acordo afetivo entre as duas partes implicadas. 


\section{Intensidade}

A intensidade é o "coração da trama" (BARONI \& CORBELLARI, 2011), e ela "depende em grande parte da iminência pressentida de um desfecho a vir" (BARONI, 2007, p. 31). A intensidade, logo, como uma tensão, seguida de uma resolução, de um relaxamento. Mas a intensidade é também mais que isto, mais que um momento da tensão narrativa. É justamente o que o conceito de formas de vitalidade permite formular mais precisamente, considerando-se as numerosas implicações. Eis algumas.

(1) As formas de vitalidade permitem compreender a natureza própria das tensões que se enlaçam no nível da trama. Pois, sem forma de vitalidade, não há conteúdo:

[...] o fio da vitalidade dinâmica é o mais fundamental e o mais primário. O fio da modalidade do conteúdo deve ser codificado ao longo ou no entorno (por assim dizer) do fio da vitalidade dinâmica. Ele reveste sua forma fenomênica e nos aparece apenas quando está enrolado no entorno do fio da vitalidade dinâmica. É mais que uma 'incarnação'. Na falta do fio da vitalidade dinâmica, o registro da modalidade do conteúdo seria numérico e não teria jamais o aspecto dinâmico e analógico da atividade humana. Não haveria fluxo, vitalidade, vida (STERN, 2010 [2010], p. 37-38; cf. 34-35).

(2) As formas de vitalidade concedem assim uma forma dinâmica aos nós que ritmam a tensão narrativa. Mas, sobretudo, elas multiplicam esses nós de tensão no próprio seio da sequência narrativa, na medida em que implicam todos os parâmetros possíveis ao mesmo tempo em que dizem respeito frequentemente aos micro-instantes. Em música, formas de vitalidade - "as variações de ativação e excitação" (ibid., p. 97) - podem surgir no entorno de uma mudança de intensidade, de ritmo ou 
de tempo, ou ainda de um acento, de uma ligação, etc. (cf. ibid., p. 104107). As formas de vitalidade aparecem assim, no seio de uma trama, como multiplicadores de tensão, ou de "excitação", para retomar o termo de Daniel Stern (ibid., p. 73-92).

Michel Imberty retomou o conceito forma de vitalidade (que Daniel Stern chama ainda "afetos de vitalidade"), para aplicá-lo à música: "Toda mudança, todo afeto de vitalidade descreve um contorno temporal. É sua combinação dentro de uma experiência mais vasta que constitui a trama temporal de experimentar" (IMBERTY, 2005, p. 207), que recobra "ao mesmo tempo a forma de sentir a experiência e a intensidade da tensão" (ibid., p. 209). Michel Imberty propõe, desse ponto de vista, análises de obras de Debussy, de Webern e, sobretudo, o Erwartung de Schoenberg (cf. ibid., p. 210-232). Assim, nesta obra, o experimentar é sobretudo baseado nas intensidades e nas tensões, nas acelerações, nas desacelerações, nos crescendi e diminuendi, etc." (ibid., p. 212 ; cf. p. 225).

(3) O conceito de formas de vitalidade permite igualmente abordar a questão da interpretação. Com efeito, "a dinâmica da vitalidade é um aspecto fundamental da prestação nas artes do espetáculo vivente. As formas dinâmicas de uma peça de música figuram em outro lugar na partitura. Ademais, para além destas indicações, a diferença entre uma prestação tecnicamente bem-sucedida e uma interpretação que nos transporta reside na dinâmica da vitalidade única que um grande artista pode trazer à obra e transmitir a um público" (STERN, 2010, p. 131).

(4) Enfim, "as formas de vitalidade são independentes da modalidade", e não pertencem, portanto, "a uma modalidade sensorial específica, mas a todas (visão, olfato, tato, etc.)" (ibid., p. 38). As formas 
de vitalidade são, em consequência, metamodais: "a dinâmica da experiência aparece em todas as formas de arte, porque falam a mesma língua metamodal das formas de vitalidade, com ou sem emoções identificáveis" (ibid., p. 103).

Eis alguns exemplos da função essencial das formas de vitalidade na interação entre leitor e texto, do ponto de vista de sua própria possibilidade, e de sua intensidade. Além disto, o caráter metamodal das formas de vitalidade permite compreender outra grande função percebida por nós: a sintonização.

\section{A sintonização afetiva}

Daniel Stern estudou o fenômeno da "sintonização afetiva" a partir do modelo da relação, das interações entre a mãe e o bebê. Eis o princípio: há "uma concordância de estados emocionais internos, e não de comportamentos manifestos", fundados sobre as formas de vitalidade - dos "traços dinâmicos" - relevantes de modalidades diferentes e nãoverbais. Por exemplo: o bebê mostra sua alegria por ter pego qualquer coisa e a mãe indica que o compreende ao responder através de um "sim" cantarolado que toma a mesma curva dinâmica - ou forma de vitalidade - que aquela utilizada pelo bebê. A sintonização afetiva é assim "fundada sobre a concordância e partilha de formas de vitalidade dinâmica colhendo de modalidades diferentes", e seu "emprego frequente permite a uma mãe criar um grau de intersubjetividade mais alto que a imitação fiel". Dito de outra maneira, um "certo sentimento de compreensão interna" pode ser assim estabelecido (para esse parágrafo, cf. STERN, 2010 [2010], p. 55-56; ver também, para a sintonização afetiva, cf. STERN 1989 [1985], p. 181-208). 
Não há, contrariamente às aparências, uma "imitação recíproca da mãe e da criança":

O ajuste não é somente o de imitar de perto o outro de perto, mas primeiramente encontrar a correspondência afetiva exata, para além das formas exteriores percebidas da conduta, portanto de encontrar essa 'cor' ou 'tonalidade' sentida e doravante partilhada fazendo uso no caso de todas as capacidades de transposição transmodal das quais é capaz a criança; logo, trata-se de que mãe e o bebê se sintonizem, [...] para entrar em ressonância emocional um com o outro, e que partilhem os afetos de vitalidade" (IMBERTY, 2005, p. 200).

E Michel Imberty dá o exemplo de musicistas (um quarteto) tocando juntos:

compreendemos facilmente que eles tem que partilhar o conjunto dos afetos de vitalidade, não somente aqueles que podem sentir em si mesmo na sua interação com os outros membros do quarteto, mas igualmente aqueles que Ihes sugere a música e que também devem partilhar. Ou, para que o conjunto seja homogêneo, para que a unidade do conjunto e do tom seja possível, é necessario que se ajustem uns aos outros, que se ouçam para se sintonizarem, não somente do ponto de vista dos parâmetros objetivos (afinação, tempo, fraseado, acentos, ...) mas também do ponto de vista do sentir a música que tocam. Isso faz portanto com que sua sintonia deva também deva ser uma sintonia afetiva (IMBERTY, 2005, p. 199).

\section{Conclusão}

A sintonia afetiva, e mais genéricamente, as formas de vitalidade, cumprem uma função essencial dentro da trama e quanto ao grau de intensidade de uma interação entre o leitor e um texto, musical ou outro. De fato, os três fatores examinados nessa última parte intencionalidade, embodied simulation, formas de vitalidade - são indissociáveis, sendo todas necessárias para que haja interação - dito de 
outro modo, no sentido de Raphël Baroni, para que haja realização para o leitor da trama de uma obra, portanto das tensões que prescrutam esta, e de suas resoluções. Esse fluxo de narratividade, o nomeamos narratividade intriga. Que se inscreve necessariamente dentro de uma moldura temporal, que corresponde à maneira - ao mesmo tempo coletiva e individual - de problematizar o tempo, um fluxo de narratividade chamado narratividade moldura. Todavia, estes dois fluxos semióticos de narratividade constituem tão somente - para retomar a distinção de Daniel Charles - o "ruído de fundo" em relação a um fluxo de narratividade primeira, interrompida, que penetra toda música: a narratividade substância. Há "o ruído da forma", que reverbera todos os ruídos do mundo. E a música - toda música - faz assim ouvir, ressoar, "o próprio ruído do existir".

\section{Referências :}

ALMÉN, B. (2008) A Theory of Musical Narrative. Bloomington : Indiana University Press.

ARBO, A. (2010) Archéologie de l'écoute. Essais d'esthétique musicale. Paris : L'Harmattan.

BARONI, R. (2011) "Tensions et résolutions : musicalité de l'intrigue ou intrigue musicale ?" In Cahiers de Narratologie [En ligne], 21, mis en ligne le 21 décembre 2011. URL : http://narratologie.revues.org/6461 (visité le 13 avril 2012).

----------(2010) "Réticence de l'intrigue". In Narratologies contemporaines. Approches nouvelles pour la théorie et l'analyse du récit. J. Pier et $\mathrm{F}$. Berthelot (Éd.), Paris : Éditions des Archives Contemporaines : 199-213.

Éditions du Seuil.

et Corbellari, A. (2011). "Introduction. Rencontres de narrativités : perspectives sur 'l'intrigue musicale'". In Cahiers de Narratologie [En ligne], 21, mis en ligne le 21 décembre 2011. URL : http://narratologie.revues.org/6461 (visité le 13 avril 2012). 
CHARLES, D. (2009) “'Le rythme comme expérience du temps”. In Filigrane [Em ligne], Musique et rythme, 10, mis à jour le 1/6/2011. URL : http://revues.mshparisnord.org/filigrane/index.php?id=325

- (2001) La Fiction de la postmodernité selon l'esprit de la musique.

Paris : Presses Universitaires de France.

COX, A. (2011) "Embodying Music : Principles of the Mimetic Hypothesis". In Music Theory in Line, a journal of the Society for Music Theory 17/2 : 1-24. URL : http://www.mtosmt.org/issues/mto.11.17.2/mto.11.17.2.cox.html\#Beginning

DARSEL, S. (2010) De la musique aux émotions. Une exploration philosophique. Rennes: Presses Universitaires de Rennes.

FREEDBERG, D. et GALLESE, V. (2007) "Motion, emotion and empathy in esthetic experience". In Cognitive Sciences, Vol. No 5: 198-203. Doi : 10.1016/j.tics.2007.02.003.

GRABÓCZ, M. (2011) "Métamorphoses de l'intrigue musicale (XIXe-XXe siècles)". In Cahiers de Narratologie [En ligne], 21, mis en ligne le 21 décembre 2011. URL : http://narratologie.revues.org/6461 (visité le 13 avril 2012).

---------- (2009) Musique, narrativité, signification. Préface de Charles Rosen, Paris : L'Harmattan.

(1986) Morphologie des oeuvres pour piano de Liszt. Influence Du programme sur l'évolution des formes instrumentales. Paris : Kimé.

HATTEN, R. (2004) Interpreting Musical Gestures, Topics, and Tropes: Mozart, Beethoven, Schubert. Bloomington and Indianapolis : Indiana University Press.

--------- (1994) Musical Meaning in Beethoven : Markedness, Correlation, and Interpretation. Bloomington and Indianapolis : Indiana University Press.

HAUER, C. (2015, à paraître) "Une approche cognitive de la narrativité musicale". In Cahiers de Narratologie [En ligne], 28. URL : http://narratologie.revues.org/

-(2014) "Le narrateur en musique comme lieu du sens". In Ontologies de la création en musique. Des lieux en musique. C. Esclapez (Éd.), Paris : L'Harmattan : 97-122.

-(2009) "L'herméneutique comme expérience universelle et science Du langage musical. - De Schleiermacher à Hjelmslev, via Ricoeur". In Le sens langagier du musical : Semiosis et hermeneia. B. Vecchione et C. Hauer (Éd.), Paris : L'Harmattan : 235-249.

(2007) "Pour une herméneutique de la création et de la réception musicales". In Sens et signification en musique. M. Grabócz (Éd.), Paris : Hermann Éditeurs : 123-132. 
(2003) "Hermeneutics of Musical Creation : Schoenberg's String Quartet No. 2 Opus 10". In Musical Semiotics Revisited. E. Tarasti (Éd.), Helsinki : Acta Semiotica Fennica XV, Approaches to Musical Semiotics 4, Studia Musicologica Universitatis Helsingiensis IX : 520-530.

HURON, D. (2006) Sweet Anticipation. Music and the Psychology of Expectation. The MIT Press.

IMBERTY, M. (2013) "Mouvement, geste et figure : la musique ancrée dans le corps". In Expression et geste musical. S. Kogler et J. P. Olive (Éd.), Paris : L'Harmattan : 25-36.

- (2005) La musique creuse le temps. De Wagner à Boulez : musique, psychologie, psychanalyse. Paris : L'Harmattan.

--------- (2004 [2002]) "La musique et l'inconscient". In Musiques. Une encyclopédie pour le XXIe siècle. 2. Les savoirs musicaux. J.-J. Nattiez (Éd.), Arles : Actes Sud : 390-418.

--------- (2003 [2001]) "Continuité et discontinuité". In Musiques. Une encyclopédie pour le XXIe siècle. 1. Musiques du XXe siècle. J.-J. Nattiez (Éd.), Arles : Actes Sud : 632-655.

(1981) Les écritures du temps. Paris : Dunod.

JOUVE, V. (2010) Pourquoi étudier la littérature ? Paris: Armand Colin.

MEISTER, J. C. (2011) "Narratology". In Handbook of Narratology. In The living handbook of narratology. P. Hühn et al. (Éd.), Hamburg : Hamburg University. URL : http://www.lhn.uni-hamburg.de/article/narratology (visité en 2012).

MEYER, L. B. (2011 [1956]) Émotion et signification en musique. Préface de J.-J. Nattiez, traduit de l'anglais par C. Delaruelle, Arles : Actes Sud.

NÜNNING, A. (2010) "Narratologie ou narratologies ? Un état des lieux des développements récents : propositions pour de futurs usages du terme". In Narratologies contemporaines. Approches nouvelles pour la théorie et l'analyse Du récit. J. Pier et F. Berthelot (Éd.), Paris : Éditions des Archives Contemporaines $: 15-44$.

PIER, J. (2010) "Configurations narratives". In Narratologies contemporaines. Approches nouvelles pour la théorie et l'analyse du récit. J. Pier et F. Berthelot (Éd.), Paris : Éditions des Archives Contemporaines : 173-197.

et BERTHELOT, F. (2010) “Introduction". In Narratologies contemporaines. Approches nouvelles pour la théorie et l'analyse du récit. J. Pier ET F. Berthelot (Éd.), Paris : Éditions des Archives Contemporaines : 7-14. 
PIGNOCCHI, A. (2015) Pourquoi aime-t-on un film? Quand les sciences cognitives discutent des goûts et des couleurs. Préface de L. Jullier, Paris : Odile Jacob.

(2012) L'oeuvre d'art et ses intentions. Préface de J.-M. Schaeffer, Paris : Odile Jacob.

RICOEUR, P. (2013) Cinq études herméneutiques. Paris : Labor et Fides.

SCHAEFFER, J.-M. (2012) "Préface". In L'oeuvre d'art et ses intentions. A. Pignocchi, Paris : Odile Jacob : 7-11.

- (2011) Petite écologie des études littéraires. Pourquoi ET comment étudier la littérature? Paris : Éditions Thierry Marchaisse.

---------- (2010) "Le traitement cognitif de la narration". In Narratologies contemporaines. Approches nouvelles pour la théorie et l'analyse Du récit. J. Pier et F. Berthelot (Éd.), Paris : Éditions des Archives Contemporaines : 215-231.

(2007) "Avant-propos". In La Tension narrative. Suspense, curiosité et surprise. R. Baroni, Paris : Seuil : 11-15.

SEVILLA, G. (2014) "La triple tension narrative : chrono-topique, pathétique, télique". In Cahiers de Narratologie [En ligne], 26, mis en ligne le 17 septembre 2014. URL : http://narratologie.revues.org/6901 (visité le 20 octobre 2014).

STERN, D. N. (2010 [2010]) Les formes de vitalité. Psychologie, arts, psychothérapie et développement de l'enfant. J. Henry (trad.), Paris : Odile Jacob.

(1989 [1985]) Le monde interpersonnel du nourrisson. Une perspective psychanalytique et développementale. A. Lazartigues et D. Pérard (trad.), Paris : Presses Universitaires de France.

TARASTI, E. (2006 [2002]) La musique et les signes. Précis de sémiotique musicale. Édition établie, traduite et revue par D. Charles et E. Gorge, Paris : L'Harmattan. 